Pacific Journal of Mathematics

A MULTIPLIER THEOREM 


\title{
A MULTIPLIER THEOREM
}

\section{Louis Pigno}

\begin{abstract}
Let $G$ be a locally compact abelian group and $\varphi$ a complex-valued function defined on the dual $\Gamma$. In this paper we prove that $\varphi$ is a multiplier of type $\left(L^{1} \cap L^{\infty}, L^{1} \cap C\right)$ if and only if $\varphi=\hat{f}$ for some $f \in L^{1}(G)$.
\end{abstract}

Throughout the paper $M(G)$ denotes the measure algebra of the locally compact group $G, L^{p}(G)(1 \leqq p \leqq \infty)$ the usual Lebesgue space of index $p$ formed with respect to left Haar measure on $G, C(G)$ the set of all bounded continuous complex-valued functions on $G$ and $C_{o}(G)$, the set of all $f \in C(G)$ which vanish at infinity.

For a locally compact abelian group $G$ with dual $\Gamma$ the Fourier transform $\hat{f}$ of a function $f \in L^{1}(G)$ is defined by

$$
\hat{f}(\gamma)=\int_{G} f(x)(-x, \gamma) d x \quad(\gamma \in \Gamma) .
$$

The Fourier-Stieltjes transform $\hat{\mu}$ of a measure $\mu \in M(G)$ is defined by

$$
\hat{\mu}(\gamma)=\int_{G}(-x, \gamma) d \mu(x) \quad(\gamma \in \Gamma) .
$$

For $y \in G$, the translate $f_{y}$ of the function $f$ is defined by

$$
f_{y}(t)=f(t-y) \quad(t \in G) .
$$

The translate $\mu_{y}$ of the measure $\mu \in M(G)$ is defined by

$$
\mu_{y}(E)=\mu(E-y)
$$

where $E$ is any Borel set in $G$.

A complex-valued function $\varphi$ defined on $\Gamma$ is said to be a multiplier of type $\left(L^{1} \cap L^{\infty}, L^{1} \cap C\right)$ if given $f \in L^{1}(G) \cap L^{\infty}(G)$ there corresponds a $g \in L^{1}(G) \cap C(G)$ such that $\varphi \hat{f}=\hat{g}$. The set of all multipliers of type $\left(L^{1} \cap L^{\infty}, L^{1} \cap C\right)$ will be denoted by $\left(L^{1} \cap L^{\infty}, L^{1} \cap C\right)$. The multiplier problem $\left(L^{1} \cap L^{\infty}, L^{1} \cap C\right)$ is then the determination of necessary and sufficient conditions which insure that $\varphi \in\left(L^{1} \cap L^{\infty}, L^{1} \cap C\right)$. The multiplier problems, $\left(L^{1} \cap L^{\infty}, L^{1} \cap C_{o}\right)$, $\left(L^{1} \cap C_{o}, L^{1}\right)$, etc., are defined similarly.

For the classical groups $\mathbf{T}$ and $\mathbf{R}$, the multiplier problem $\left(L^{1} \cap L^{\infty}, L^{1} \cap C_{o}\right)$ has been solved by Zygmund [9] and Doss $[1$, p. 191], respectively. The solution for $G=\mathrm{T}$ has also been given by Verblunsky [8, p. 303]. Edwards [3, pp. 376-378] has solved the 
problem for compact groups satisfying the first axiom of countability. Hewitt and Ross have recently solved the problem (to appear in [5]) for all compact groups. We prove for arbitrary $L C A$ groups the following theorem :

Theorem 1. $\left(L^{1} \cap L^{\infty}, L^{1} \cap C\right)=\left(L^{1} \cap L^{\infty}, L^{1} \cap C_{o}\right)=L^{1}(G)^{\wedge}$.

Proof. By $L^{1}(G)^{\wedge}$ we mean the set of $\hat{f}$ on $\Gamma$ which are Fourier transforms of functions $f \in L^{1}(G)$. Suppose $\varphi=\hat{f}$ for some $f \in L^{1}(G)$. If $g \in L^{1}(G) \cap L^{\infty}(G)$ then, by [6, p. 4], the convolution $f * g \in$ $L^{1}(G) \cap C_{0}(G)$. Thus $\varphi \in\left(L^{1} \cap L^{\infty}, L^{1} \cap C\right)$ and $\left(L^{1} \cap L^{\infty}, L^{1} \cap C_{o}\right)$.

Next suppose $\varphi \in\left(L^{1} \cap L^{\infty}, L^{1} \cap C\right)$. We first show that $\varphi=\hat{\mu}$ for some $\mu \in M(G)$. Assume temporarily that $G$ is compact. Since $\varphi \in\left(L^{\infty}, C\right)$ we have $\varphi \in\left(L^{\infty}, L^{\infty}\right)$. By a result of Edwards [3, p. 374] $\varphi=\hat{\mu}$ for some $\mu \in M(G)$.

If $G$ is a noncompact $L C A$ group we proceed as follows. $\varphi \in\left(L^{1} \cap L^{\infty}, L^{1} \cap C\right)$ implies $\varphi \in\left(L^{1} \cap C_{o}, L^{1}\right)$. Doss [1, p. 189] has proved that, for $G=\mathbf{R}, \varphi \in\left(L^{1} \cap C_{o}, L^{1}\right)$ if and only if $\varphi=\hat{\mu}$ for some $\mu \in M(\boldsymbol{R})$. We have been able to generalize his proof to noncompact $L C A$ groups, but the proof is rather lengthy. Frank Forelli has recently given a simple proof that $\left(L^{1} \cap C_{o}, L^{1}\right)=M(G)^{\wedge}$. (See Theorem 3.2 of [4].)

So for $f \in L^{1}(G) \cap L^{\infty}(G)$

$$
g(x)=\int_{G} f(x-t) d \mu(t) \text { a.e. }
$$

where $\hat{g}=\hat{\mu} \hat{f}$ and $g \in L^{1}(G) \cap C(G)$. We now show that $\mu$ is absolutely continuous with respect to Haar measure. Let $A$ be any relatively compact Borel subset of $G$ and $\psi$ the characteristic function of $A$. Then the convolution $\psi * \mu$ is equal a.e. to a continuous function. Thus for each relatively compact Borel subset $A$ of $G$ the function

$$
x \longrightarrow \mu(x+A)
$$

is equal a.e. to a continuous function. This implies by the following theorem that $d \mu(x)=f(x) d x$ for some $f \in L^{1}(G)$ and hence concludes the proof.

THEOREM 2. Let $G$ be a locally compact group and $\mu \in M(G)$ such that for each relatively compact Borel subset $A$ of $G$, the function $x \rightarrow \mu(x+A)$ is equal locally a.e. to a continuous function on $G$. Then $d \mu(x)=f(x) d x$ for some $f \in L^{1}(G)$.

Compare this with Theorem 2 of [2, p. 407], where $\mu$ can be any Radon measure but where $G$ is assumed to be a first countable $L C A$ 
group. In this connection see also 1.6 of [7, p. 230]. The proof of the present theorem may be obtained by simple modifications of the proof of Theorem (35.13) of [5], which we omit.

Remark. Let $G$ be a noncompact LCA group. Since

$$
\left(L^{1} \cap C_{o}, L^{1}\right)=M(G)^{\wedge}
$$

we have that

$$
\begin{aligned}
M(G)^{\wedge} & =\left(L^{1} \cap C, L^{1}\right) \\
& =\left(L^{1} \cap L^{P}, L^{1}\right) \\
& =\left(L^{1} \cap L^{P}, L^{1} \cap L^{P}\right) \\
& =\left(L^{1} \cap C, L^{1} \cap L^{P}\right) \\
& =\left(L^{1} \cap C_{o}, L^{1} \cap L^{P}\right) \\
& =\left(L^{1} \cap C_{o}, L^{1} \cap C_{o}\right) \\
& =\left(L^{1} \cap C_{o}, L^{1} \cap C\right) \\
& =\left(L^{1} \cap C, L^{1} \cap C\right)
\end{aligned}
$$

where $M(G)^{\wedge}$ is the set of $\hat{\mu}$ on $\Gamma$ which are the Fourier-Stieltjes transforms of measures $\mu \in M(G)$. For infinite compact groups it is false that $\left(C, L^{1}\right)=M(G)^{\wedge}$ since $\left(L^{2}, L^{2}\right)=L^{\infty}(\Gamma)$.

The author wishes to thank the referee for bringing to his attention theorem (35.13) of [5] and for the reference to [4]. Theorem (35.13) enabled the removal of the (unnecessary) hypothesis that $G$ be first countable in Theorem 1 .

\section{REFERENCES}

1. R. Doss, On the multiplicators of some classes of Fourier transforms, Proc. London Math. Soc. (2) 50 (1949), 169-195.

2. R. E. Edwards, Translates of $L^{\infty}$ functions and of bounded measures, J. Austr. Math. Soc. 4 (1964), 403-409.

3. - On factor functions, Pacific J. Math. 5 (1955), 367-378.

4. A. Figà-Talamanca and G. I. Gaudry, Multipliers and sets of uniqueness of $L^{p}$ (to appear Michigan Math. J. $17(1970)$ )

5. E. Hewitt and K. A. Ross, Abstract harmonic analysis, Vol. II, Springer-Verlag, Heidelberg and New York, 1970.

6. W.Rudin, Fourier analysis on groups, Interscience, New York, 1962.

7. - Measure algebras on abelian groups, Bull. Amer. Math. Soc. 65 (1959), 227-247.

8. S. Verblunsky, On_someclasses of Fourier series, Proc. London Math. Soc. (2) 33 (1932), 287-327.

9. A. Zygmund, Remarque sur un théorème de M. Fekete, Bull. Acad. Polonaise Sci. Lett. (1927), 343-347.

Received December 10, 1969.

Kansas State University 



\section{PACIFIC JOURNAL OF MATHEMATICS}

\section{EDITORS}

H. SAMELSON

Stanford University

Stanford, California 94305

\section{Richard Pierce}

University of Washington

Seattle, Washington 98105
J. DugundJI

Department of Mathematics

University of Southern California

Los Angeles, California 90007

RICHARD ARENS

University of California

Los Angeles, California 90024

\section{ASSOCIATE EDITORS}

\section{E. F. BeCKenBACH}

B. H. NeUmanN
K. YosHida

\section{SUPPORTING INSTITUTIONS}

\author{
UNIVERSITY OF BRITISH COLUMBIA \\ CALIFORNIA INSTITUTE OF TECHNOLOGY \\ UNIVERSITY OF CALIFORNIA \\ MONTANA STATE UNIVERSITY \\ UNIVERSITY OF NEVADA \\ NEW MEXICO STATE UNIVERSITY \\ OREGON STATE UNIVERSITY \\ UNIVERSITY OF OREGON \\ OSAKA UNIVERSITY \\ UNIVERSITY OF SOUTHERN CALIFORNIA
}

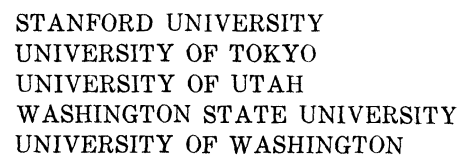

STANFORD UNIVERSITY UNIVERSITY OF TOKYO

UNIVERSITY OF UTAH

WASHINGTON STATE UNIVERSITY

UNIVERSITY OF WASHINGTON

The Supporting Institutions listed above contribute to the cost of publication of this Journal, but they are not owners or publishers and have no responsibility for its content or policies.

Mathematical papers intended for publication in the Pacific Journal of Mathematics should be in typed form or offset-reproduced, (not dittoed), double spaced with large margins. Underline Greek letters in red, German in green, and script in blue. The first paragraph or two must be capable of being used separately as a synopsis of the entire paper. The editorial "we" must not be used in the synopsis, and items of the bibliography should not be cited there unless absolutely necessary, in which case they must be identified by author and Journal, rather than by item number. Manuscripts, in duplicate if possible, may be sent to any one of the four editors. Please classify according to the scheme of Math. Rev. Index to Vol. 39. All other communications to the editors should be addressed to the managing editor, Richard Arens, University of California, Los Angeles, California, 90024.

50 reprints are provided free for each article; additional copies may be obtained at cost in multiples of 50 .

The Pacific Journal of Mathematics is published monthly. Effective with Volume 16 the price per volume (3 numbers) is $\$ 8.00$; single issues, $\$ 3.00$. Special price for current issues to individual faculty members of supporting institutions and to individual members of the American Mathematical Society: $\$ 4.00$ per volume; single issues $\$ 1.50$. Back numbers are available.

Subscriptions, orders for back numbers, and changes of address should be sent to Pacific Journal of Mathematics, 103 Highland Boulevard, Berkeley, California, 94708.

PUBLISHED BY PACIFIC JOURNAL OF MATHEMATICS, A NON-PROFIT CORPORATION

Printed at Kokusai Bunken Insatsusha (International Academic Printing Co., Ltd.), 7-17, Fujimi 2-chome, Chiyoda-ku, Tokyo, Japan. 


\section{Pacific Journal of Mathematics}

\section{Vol. 34, No. 3 \\ July, 1970}

Richard Hindman Bouldin, The peturbation of the singular spectrum

Hugh D. Brunk and Søren Glud Johansen, A generalized Radon-Nikodym derivative .

Henry Werner Davis, F. J. Murray and J. K. Weber, Families of $L_{p}$-spaces

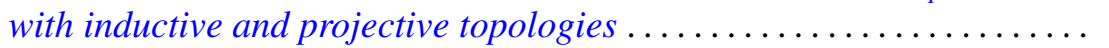

Esmond Ernest Devun, Special semigroups on the two-cell .

Murray Eisenberg and James Howard Hedlund, Expansive automorphisms

of Banach spaces ......................................

Frances F. Gulick, Actions of functions in Banach algebras.

Douglas Harris, Regular-closed spaces and proximities.

Norman Lloyd Johnson, Derivable semi-translation planes . .

Donald E. Knuth, Permutations, matrices, and generalized Young

tableaux..........................................

Herbert Frederick Kreimer, Jr., On the Galois theory of separable

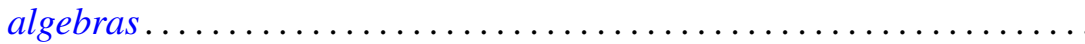

You-Feng Lin and David Alon Rose, Ascoli's theorem for spaces of

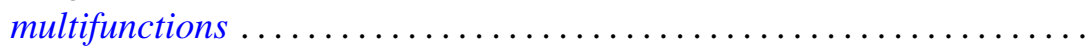

David London, Rearrangement inequalities involving convex functions . . . .

Louis Pigno, A multiplier theorem.

749

Helga Schirmer, Coincidences and fixed points of multifunctions into trees.

755

Richard A. Scoville, Some measure algebras on the integers .

Ralph Edwin Showalter, Local regularity of solutions of Sobolev-Galpern

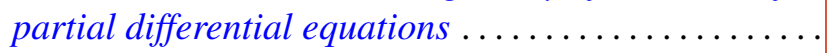

Allan John Sieradski, Twisted self-homotopy equivalences

John H. Smith, On S-units almost generated by S-units of subfields ...

803

Masamichi Takesaki, Algebraic equivalence of locally normal

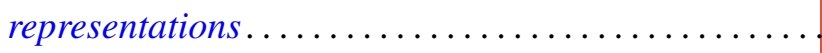

Joseph Earl Valentine, An analogue of Ptolemy's theorem and its converse in

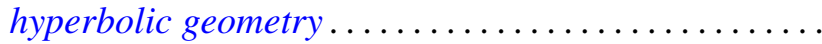

David Lawrence Winter, Solvability of certain p-solvable linear groups of finite order 